\title{
Effects of sizes of streamer tags on mortality and growth of juvenile eastern king prawns Penaeus plebejus
}

\author{
S. S. Montgomery, C. A. Gray \\ NSW Agriculture \& Fisheries, Fisheries Research Institute, PO Box 21, Cronulla 2230, NSW, Australia
}

\begin{abstract}
Under controlled conditions, juvenile eastern king prawns Penaeus plebejus (Hess) (17 to $27 \mathrm{~mm}$ carapace length, CL) tagged with small streamer tags $(80 \mathrm{~mm}$ long by $2 \mathrm{~mm}$ wide) displayed less apparent mortality (proportion of tagged prawns that either died or shed their tag) than those tagged with large streamer tags $(90 \mathrm{~mm}$ long by $3 \mathrm{~mm}$ wide). There were no significant differences in taginduced mortality or tag shedding among tag treatments. The proportion of untagged (control) prawns that died was significantly less than that of prawns tagged with either size of streamer tag. During the $60 \mathrm{~d}$ experiment, apparent mortality was greatest over the first 5 and $6 \mathrm{~d}$ for small and large tags respectively. At the end of the experiment, mean apparent mortality was 2,52 and $65 \%$ for controls, small and large tags respectively. Shedding of tags contributed 14 and $19 \%$ to the apparent mortality of prawns tagged with the small or large tags respectively. Growth increments of prawns surviving to the end of the experiment did not differ between prawns tagged with large or small tags, but did differ between sexes (females had a bigger increase in CL than males). Streamer tags of the sizes tested were considered unsuitable for tagging eastern king prawns of 17 to $27 \mathrm{~mm} \mathrm{CL}$.
\end{abstract}

\section{INTRODUCTION}

Tagging and marking organisms have been used for many years to study movements, rates of growth and mortality, and for estimating the number of individuals, in a population (Rounsfell 1963, Cormack 1968, Jakobsson 1970). In any tagging study it is important to understand how the tag or tagging operation may affect the tagged individual and hence the data collected. Quantitative analyses of tagging data that require an estimate of the total number of tagged animals need to consider tag loss and the effect of tagging on the behaviour of the tagged individual in relation to capture. On the other hand, tagging studies that are used to collect data to estimate growth parameters need to account for the effects of tagging on the growth of the tagged individual.

Tag loss may result from deaths caused by the tagging operation (tag-induced mortality), deaths from natural causes, tag shedding, non-reporting of recaptured tagged individuals and the dispersal of tagged individuals out of the study area. Beverton \& Holt (1957) identified 2 types of tag loss other than fishing that reduce the initial number of tagged fish released. Type I losses were those which reduce the number of tagged individuals over a short period of time after release. Type II losses were those which happen at approximately a constant rate throughout the tagging experiment. In the present paper, tag loss has been termed 'apparent mortality' to avoid any confusion with the discussion on 'tag shedding'.

The various types of tags and marks used to study penaeid prawns have been discussed by Neal (1969), Farmer (1981), Garcia \& Le Reste (1981), Klima (1981) and Penn (1981). Studies into the effects on penaeids of tagging suggest that tag-induced mortality is sizedependent. In some cases more smaller than large prawns die as a result of tagging (e.g. Lucas et al. 1972, Holt 1982, Howe \& Hoyt 1982, Hill \& Wassenberg 1985. Wassenberg \& Kerr 1990), and in other cases more large adults die (Penn 1975, Glaister 1983). Consequently, the range of lengths of prawns that can be tagged may be limited (e.g. Farmer \& Al-Attar 1981).

The problem of tag shedding has been considered in tagging studies on species of fish (e.g. Greenland \& Bryan 1974, Kirkwood \& Walker 1984, Hampton \& 
Kirkwood 1989) but has received scant attention in tagging studies on prawns. Howe \& Hoyt (1982) concluded from experiments in the field and laboratory using Penaeus aztecus that attempted predation caused prawns to lose tags. Prentice \& Rensel (1977) found that under laboratory conditions, $95 \%$ of juvenile Pandalus platyceros retained coded wire tags.

Studies about the effects of tagging on prawn growth have varied in their conclusions. Penn (1975) and Hill \& Wassenberg (1985) concluded that tagging experiments in the field provided accurate estimates of longterm growth. Menz \& Blake (1980) found from experiments in the field and laboratory that the growth of streamer-tagged Penaeus vannamei was 'marginally' slower than that of untagged prawns.

The eastern king prawn Penaeus plebejus (Hess) is one of a number of prawns caught along the east coast of Australia. Movements, growth and mortality of adult eastern king prawns have been studied using a variety of tags, including Petersen disks (Lucas 1974, Potter 1975), Atkins tags (Ruello 1975) and streamer tags (Glaister et al. 1987, 1990, Montgomery 1990). Streamer tags were used by Montgomery (1990) to investigate the movements of juvenile eastern king prawns because they caused less mortality amongst other penaeid species than did other types of external tags (Marullo et al. 1976, Farmer \& Al-Attar 1981). Also, these had been used successfully in studies on adult eastern king prawns (Glaister 1983, Glaister et al. 1987) and other prawn species (e.g. Somers \& Kirkwood 1984, Sheridan et al. 1987).

In the present paper we investigated tag-induced mortality and tag shedding in juvenile eastern king prawns of lengths within the range used by Montgomery (1990). We sought to investigate also the effects of tagging with streamer tags on the growth of these prawns. All this information would be useful when interpreting data from Montgomery (1990). Further, we wanted to know whether the size of streamer tags affected apparent mortality and growth in juvenile eastern king prawns. If there were such an effect, survivorship might be improved by using streamer tags of an appropriate size. The null hypothesis tested was that mortality and/or growth of either sex of juvenile penaeus plebejus was unaffected by tagging or by tag sizes.

\section{METHODS}

\section{Experimental procedure}

The experiment was carried out in $3.3 \mathrm{~m}^{2}$ netted enclosures (pens) within a 0.11 ha pond at the NSW
Agriculture \& Fisheries' Brackish Water Fish Culture Research Station, Port Stephens ( $32^{\circ} 44^{\prime}$ S), Australia. A description of the pond and apparatus used in the experiment can be found in Maguire \& Bell (1981). The pond was left dry for $1 \mathrm{wk}$ prior to the experiment to kill non-experimental prawns in the pond. During the experiment, approximately half of the water in the pond was exchanged daily with the neighbouring tidal creek. To mix the water and maintain oxygen concentration in the pens, air was pumped through an air stone at the ends of each pen.

In the experiment, 3 treatments (small tag, large tag and untagged) were applied to female and male prawns. The entire set of 6 conditions was replicated in each of 10 pens, using 5 prawns of each sex with each treatment (i.e. a total of 30 prawns per pen; 9 prawns per $\mathrm{m}^{2}$ ). Streamer tags (FTSL-73; Floy Tag and Manufacturing, Inc.) were used. Small tags were made of $80 \mathrm{~mm}$ long, $2.2 \mathrm{~mm}$ wide and $0.1 \mathrm{~mm}$ thick polyethylene strips and had $1.5 \mathrm{~mm}$ wide central sections which locked the tags in place through the prawns. Large tags were $90 \mathrm{~mm}$ long, $3.2 \mathrm{~mm}$ wide and $0.15 \mathrm{~mm}$ thick, with $2 \mathrm{~mm}$ wide central sections. Small and large tags were passed through prawns with needles of diameter 0.6 and $1 \mathrm{~mm}$, respectively.

\section{Handling and holding prawns}

Eastern king prawns of 17 to $27 \mathrm{~mm}$ carapace length (CL) were collected from unsorted catches of commercial fishing operations (commonly referred to as pocket-netting) in Wallis Lake, New South Wales $\left(30^{\circ} 09^{\prime} \mathrm{S}\right)$. Prawns were placed on trays of wire mesh and stacked into a 2500 l aerated saltwater tank which was transported for $4 \mathrm{~h}$ to the research station. The experiment was started as soon as possible after capture (within 24 h of the prawns' capture) to simulate, as closely as possible, tagging operations used in the field by Montgomery (1990).

Trays containing prawns were transferred from the tank into 450 l containers of aerated saltwater, when required. Prawns were selected from these trays at random and treated with one of the 3 treatments. Tags were inserted through the articular membrane of prawns between the first and second abdominal segments and in a position which avoided nervous and digestive tissue. Prawns were measured (to the nearest whole $\mathrm{mm}$ ) between the base of the orbit of the eye and the centre of the posterior margin of the carapace (carapace length), using dial calipers. The sex of the prawn was determined by the presence of a thelycum (females) or petasma (males).

Dead prawns, loose tags and exuviae were removed from each pen, every $12 \mathrm{~h}$. At the same 
time, variations in temperature and salinity at 4 fixed sites on the bottom of the pond were recorded using maximum/minimum thermometers $\left(1^{\circ} \mathrm{C}\right.$ divisions $)$ and a salinity/temperature meter respectively. Prawns were fed daily using meat from the bivalve Donax deltoides, at a rate of ca $5 \%$ of the body weight of prawns (calculated from length-weight relationships in Glaister 1983), in the particular pen (Maguire \& Leedow 1983).

After $60 \mathrm{~d}$, each pen was lifted from the pond and washed clean of sediment, and all remaining prawns, exuviae and loose tags were collected. Dead prawns and exuviae collected throughout the experiment and all prawns at the end of the experiment were sexed, measured and inspected for evidence of a tag wound. Where applicable, the tag number of the prawn was also recorded.

\section{Analysis of data}

Tag-induced mortality and tag shedding were expressed for each treatment in each pen as the proportion of prawns released that died or shed their tag,

Table 1. Penaeus plebejus. Analysis of variance of proportional deaths, tag shedding and apparent mortality of eastern king prawns during the $60 \mathrm{~d}$ experiment. At the start, 5 male and 5 female prawns in each of 10 replicates of 3 treatments were tagged with small or large streamer tags, or untagged (controls). Variances were homogeneous (Cochran's test, $p>0.05) .(=)$ in Student-Newman-Keuls tests denotes no significant difference between 2 means

\begin{tabular}{|c|c|c|c|c|}
\hline $\begin{array}{l}\text { Analyses of varianc } \\
\text { Source }\end{array}$ & \multicolumn{3}{|c|}{ Analyses of variance, $n=10$ replicates } & $\mathrm{p}$ \\
\hline \multicolumn{5}{|l|}{ Deaths } \\
\hline Treatment & 2 & 1.07 & 23.50 & $<0.05$ \\
\hline Sex & 1 & 0.07 & 1.61 & $>0.20$ \\
\hline Treatment $\times$ Sex & 2 & 0.03 & 0.62 & $>0.50$ \\
\hline Residual & 54 & 0.05 & & \\
\hline \multicolumn{5}{|l|}{ Tag shedding } \\
\hline Treatment & 1 & 0.10 & 0.38 & $>0.5$ \\
\hline Sex & 1 & 0.09 & 2.72 & $>0.1$ \\
\hline Treatment $\times$ Sex & 1 & 0.01 & 0.28 & $>0.50$ \\
\hline Residual & 36 & 0.03 & & \\
\hline \multicolumn{5}{|c|}{ Deaths + Tag shedding (apparent mortality) } \\
\hline Treatment & 2 & 2.21 & 53.67 & $<0.05$ \\
\hline Sex & 1 & 0.01 & 0.18 & $>0.60$ \\
\hline Treatment $\times$ Sex & 2 & 0.01 & 0.17 & $>0.80$ \\
\hline Residual & 54 & 0.04 & & \\
\hline \multicolumn{5}{|c|}{ Student-Newman-Keuls tests } \\
\hline & Large tag & $\begin{array}{l}\text { Trea } \\
\text { Sma }\end{array}$ & $\begin{array}{l}\text { ment } \\
\text { l tag }\end{array}$ & Control \\
\hline Deaths & 0.46 & $=$ & $>$ & 0.02 \\
\hline Apparent mortality & 0.65 & $>$ & $>$ & 0.02 \\
\hline
\end{tabular}

respectively. Similarly, apparent mortality was expressed as the proportion of prawns released that had either died or shed their tag. Tag-induced mortality, tag shedding and apparent mortality after $60 \mathrm{~d}$ for each of the 3 treatments were compared using a 2-factor orthogonal ANOVA. Student-Newman-Keuls (SNK) multiple comparisons were used to isolate significant differences among treatments in the ANOVA.

To determine the effects of tagging on prawn growth, lengths of prawns that survived to the end of the experiment were compared using analysis of covariance (ANCOVA), with the initial length of each prawn as the covariate. As an alternative analysis, data were adjusted for any influences of initial length of prawns. This was done by randomly selecting a balanced sub-set of survivors from each treatment and sex. The growth increment over $56 \mathrm{~d}$ of each member of the sub-set was then adjusted as follows:

$$
L_{i j}=\frac{l_{t i j}-l_{0 i j}}{l_{O i j}}
$$

where $L_{i j}=$ adjusted growth increment; $I_{t i j}=$ length of a prawn of gender $i$ in treatment $j$ that survived for $56 \mathrm{~d}$; $l_{0 i j}=$ initial mean length of all experimental prawns of gender $i$ in treatment $j$. The null hypothesis that there was no difference in growth between tag types was then tested using a 2-factor orthogonal ANOVA.

\section{RESULTS}

\section{Mortality and tag shedding}

At the end of the experiment, $96 \%$ of the tagged prawns, and all untagged prawns (controls), were accounted for. The most likely scenarios for the unaccountable $4 \%$ were either: (1) prawns had escaped from the pens or had been eaten by other animals in the pens, or (2) tags had been dislodged from the prawns and were not found. These prawns were discarded from the data set and, because they were few, did not alter any conclusions.

The proportion of prawns that had died by the end of the experiment differed significantly among the 3 treatments (Table 1). The proportion of untagged (control) prawns $(2 \%)$ that died was less than that amongst prawns tagged with large tags $(46 \%)$ and those tagged with small tags (38\%; SNK test in Table 1$)$. There were no significant differences among treatments in the proportion of prawns that shed their tags (14 and $19 \%$ for small and large tags respectively), but there were differences in apparent mortality (SNK test in Table 1). Mean apparent mortality over the whole experiment was $2 \%$ of untagged (control) prawns, $52 \%$ of prawns 
tagged with small tags and $65 \%$ of those with large tags. There were no differences between sexes in apparent mortality, tag-induced mortality or tag shedding within treatments, so sexes were combined for Fig. 1.

Patterns in tag-induced mortality and apparent mortality over time amongst prawns tagged with either the small or large tags were similar (Fig. 1). Only 2 untagged prawns died during the experiment fon Days 1

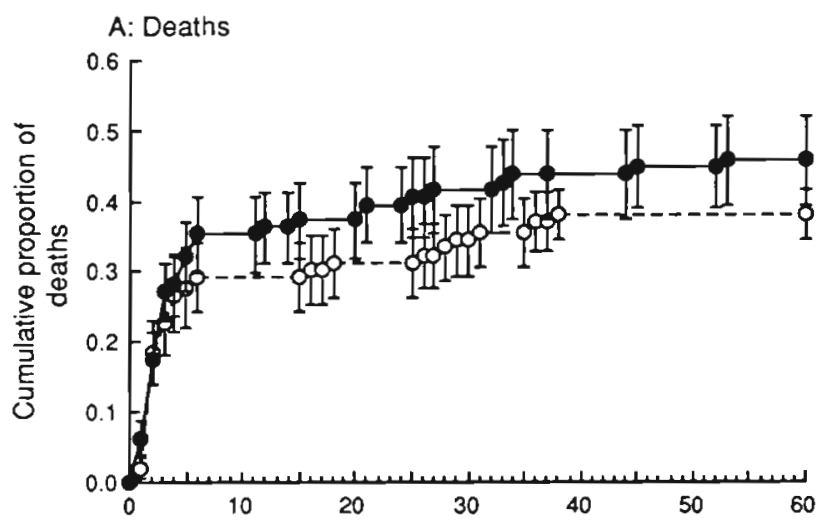

B: Tags shed

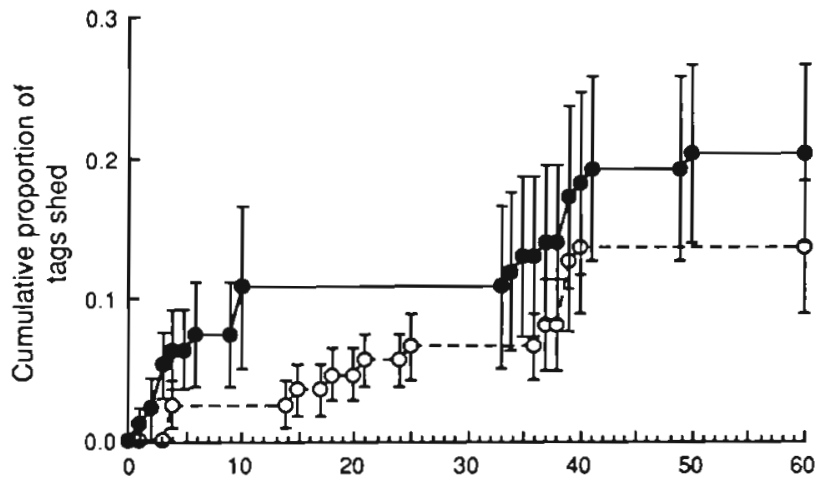

C: Apparent mortality

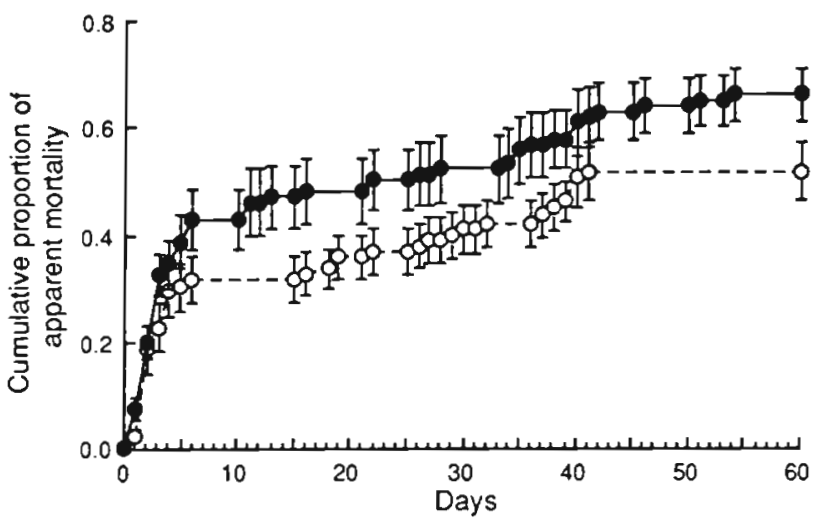

Fig. 1. Penaeus plebejus. Mean cumulative proportion of eastern king prawns, tagged with large $(\bullet)$ or small $(\omega)$ streamer tags, that $(A)$ died or $(B)$ shed their tag, and (C) the proportion when these effects were combined (apparent mortality), in 10 replicates. Standard error of mean also shown
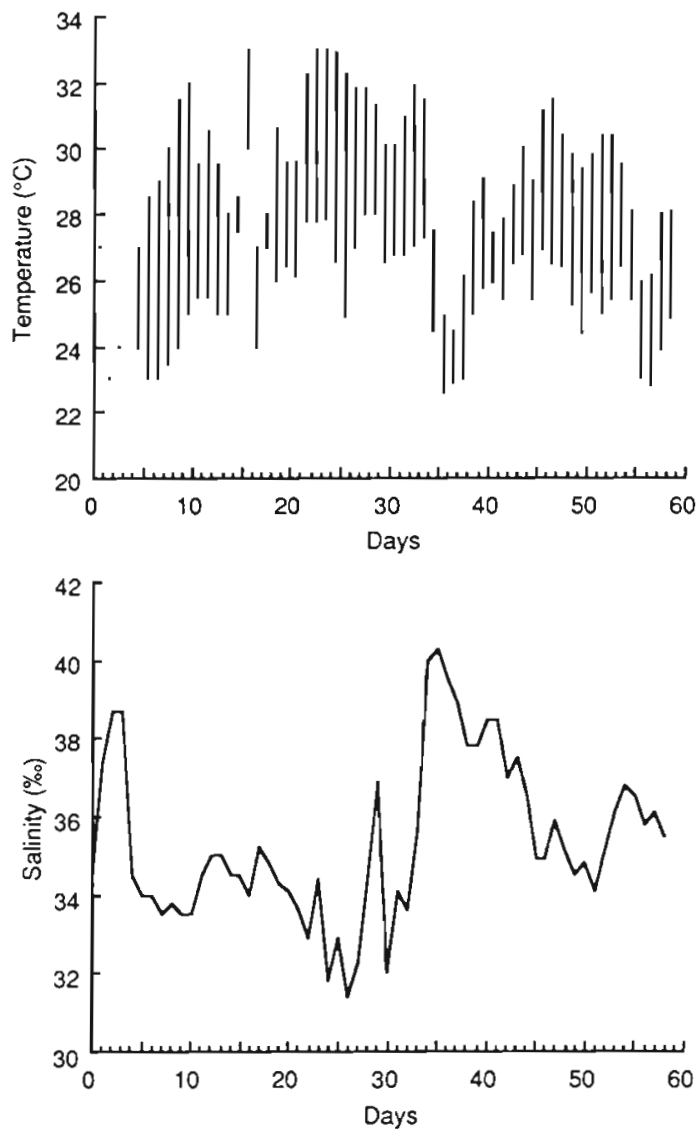

Fig. 2. Variation in mean maximum and minimum water temperature and mean salinity measured at 4 sites in the pool

and 2 respectively). The instantaneous rate of taginduced mortality and apparent mortality was greatest during the first $6 \mathrm{~d}$ of the experiment for prawns tagged with small and large tags respectively. Tag-induced mortality continued after this, but at a slower rate than before. The pattern in tag shedding varied slightly among tag treatments. The incidence of tag shedding among prawns tagged with large tags was greatest during Days 0 to 4 and 33 to 41 . On the other hand, there were no small tags shed from prawns until Day 4 of the experiment, and the incidence of shedding of small tags was greatest on Day 5 and during Days 14 to 21 and 36 to 40 . The instantaneous rate of apparent mortality after Day 6 was slower than before, except for brief periods between Days 33 and 42 and Days 35 and 41 for large and small tags respectively. These periods coincided with increases in the instantaneous rate of tag shedding and a sudden rise in temperature and decrease in salinity in the pond (Fig. 2). No further apparent mortality occurred after the 40th day amongst prawns tagged with a small tag, but those with a large tag continued to die or shed their tag (although at a slower rate). 

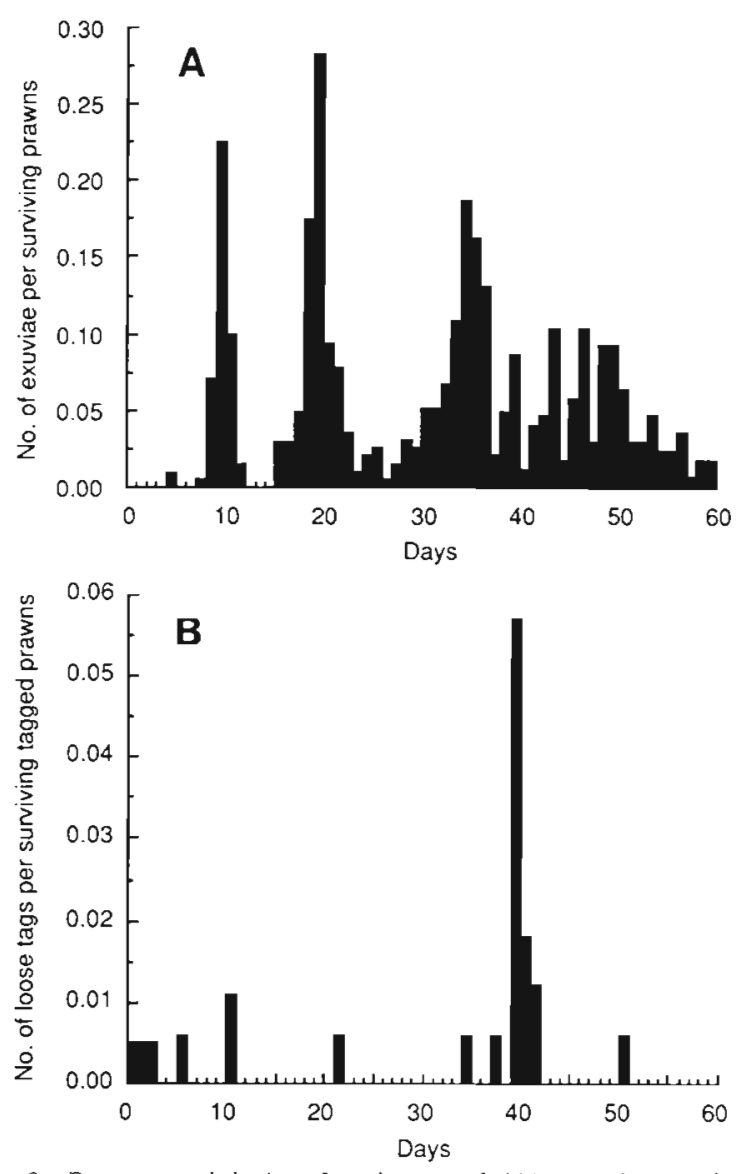

Fig. 3. Penaeus plebejus. Incidence of (A) exuviae and (B) loose tags from tagged and untagged eastern king prawns in the experiment

\section{Growth and moulting}

The frequency of moulting peaked at Days 10, 20 and 35 (Fig. 3) and then became more irregular The irregular pattern occurred when there had been a sudden rise in temperature and decrease in salinity (Fig. 2). In most cases, it was impossible to distinguish between exuviae from tagged and untagged prawns. We could not ascertain, therefore, whether there were any differences in the pattern of moulting between tagged and untagged prawns. Some exuviae with an obvious wound site from tagging were found at all times when there was a peak in the frequency of moulting. Loose tags were found during each period of high moult frequency but most were found on Day 40.

There were no differences among treatments in the length-frequency distributions of prawns at release (Kolmogorov-Smirnov tests; $p>0.01$ ). The distribution of lengths of prawns at release that survived to the end of the experiment also was not significantly different between the 2 tag sizes (Fig. 4; Kolmogorov-Smirnov test; $D_{\max }=0.22$ and 0.21 for large and small tags respectively, $\mathrm{p}>0.01$ ).

There were no significant differences among the 3 treatments in the slopes of the regressions of growth increment of surviving prawns on initial carapace length (ANCOVA; Table 2). There were, however, significant differences in the intercepts of these regressions between sexes and the interaction of sex and tag type. The latter was caused by the influence of sex, since there were no differences between tag types in the intercepts of growth increment on initial carapace length. This result was the same when growth increments were adjusted for initial mean length (ANOVA; Table 2). Females had a larger increase in carapace length than males.

\section{A: Small tag}

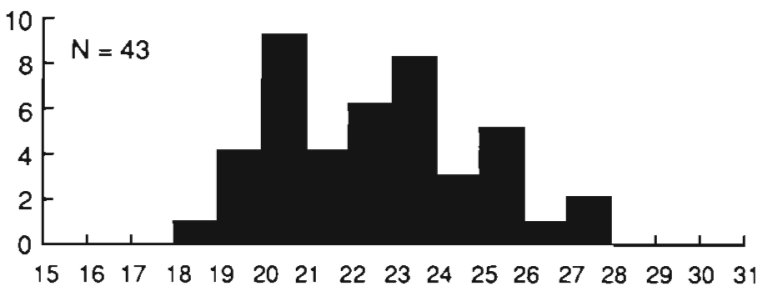

B: Large tag
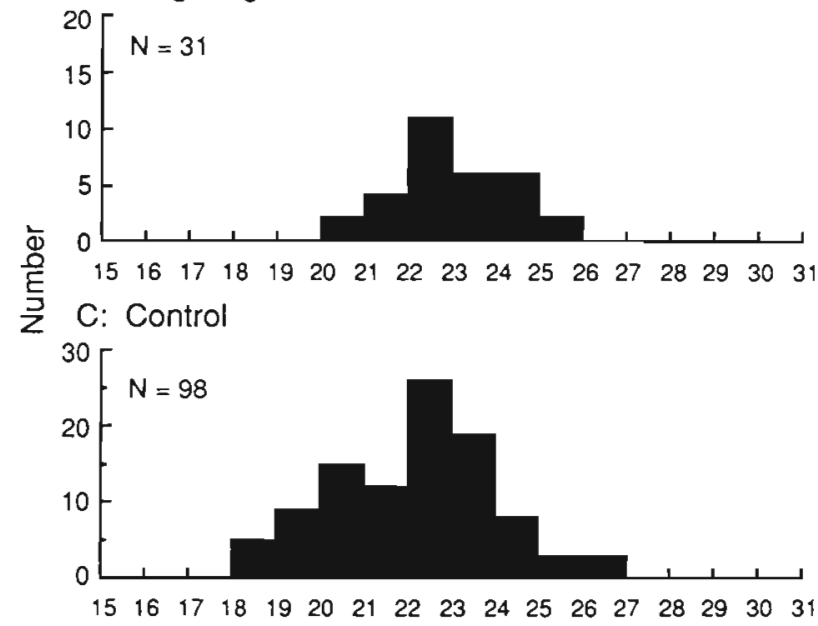

D: All

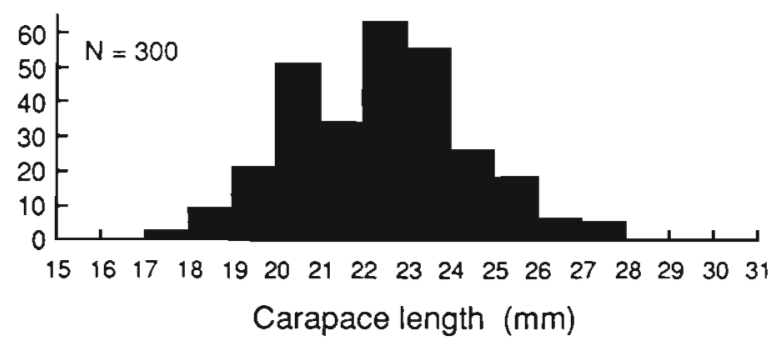

Fig. 4. Penaeus plebejus. (A to C) Distribution of lengths at release of eastern king prawns in each treatment that survived to the end of the experiment. (D) Distribution of lengths of all prawns at release 
Table 2. Penaeus plebejus. Analysis of growth (in terms of increase in carapace length) of tagged eastern king prawns that survived to the end of the experiment. Data were tested (a) using analysis of covariance of regressions of growth increment on initial carapace length, and (b) a sub-set was also tested by analysis of variance (variances were homogeneous; Cochran's test, $p>0.05$; see 'Methods')

\begin{tabular}{|lrrrc|}
\hline Source of variation & df & MS & $F$ & $p$ \\
\hline (a) ANCOVA & & & & \\
Slopes & 3 & 0.19 & 0.14 & $>0.50$ \\
Residual & 67 & 1.35 & & \\
Intercepts & & & & \\
$\quad$ Type of tag & 1 & 2.20 & 1.70 & 0.10 \\
$\quad$ Sex & 1 & 32.74 & 25.24 & $<0.001$ \\
$\quad$ Tag $\times$ Sex & 1 & 5.37 & 4.14 & $<0.05$ \\
Residual & 70 & 1.30 & & \\
(b) ANOVA & & & & \\
Type of tag & 2 & 0.01 & 3.02 & $>0.05$ \\
Sex & 1 & 0.04 & 8.70 & $<0.005$ \\
Tag $\times$ Sex & 2 & 0.0004 & 0.15 & $>0.50$ \\
Residual & 84 & 0.005 & & \\
\hline
\end{tabular}

\section{DISCUSSION}

Results from the present study showed that tagging affects eastern king prawns in the 17 to $27 \mathrm{~mm} \mathrm{CL}$ range. Apparent mortality of tagged prawns in the present study included 2 components, namely, the mortality induced by tagging, and tag shedding. These have the effect of making the number of tagged prawns in the population less than the number released. If the effects of tagging are not considered, mortality and rates of recruitment to the fishable stock for eastern king prawns that are calculated from data from tagging experiments will be underestimated.

Growth of prawns was unaffected by the size of the tag used but was affected by the sex of the prawn. This was true regardless of whether data were adjusted for the initial lengths of prawns. We could not use the growth increment of individual prawns to compare the growth rates of tagged and untagged (control) prawns, because untagged prawns could not be differentiated in all cases from those prawns that had shed their tag. The unimodal shape of each peak in the frequency distribution of moulting suggested either that large numbers of only tagged or untagged prawns were moulting, or that there were no differences in intermoult period between untagged and tagged prawns. Intermoult period has been shown to vary between tagged and untagged prawns (e.g. Penn 1975, Hill \& Wassenberg 1985).

Patterns in tag-induced mortality over time in this study were similar to those described previously for this species (Lucas et al. 1972, Glaister 1983) and other species of prawns (e.g. Marullo et al. 1976. Howe \& Hoyt 1982, Jewett 1986). Estimates of tag-induced mortality in the present study were greater than found in other investigations for this (Glaister 1983) and for other penaeids (e.g. Marullo et al. 1976, Farmer \& Al-Attar 1981, Hill \& Wassenberg 1985), but were similar to those found by Howe \& Hoyt (1982) for Penaeus aztecus and by Jewett (1986) for Pandalus platyceros. These greater values than those found by Glaister (1983) suggested that tag-induced mortality may be size-dependent in eastern king prawns. Size-dependent tag-induced mortality for this species was also suggested by Lucas et al. (1972) using Petersen disks or anchor tags and has been found for other species of penaeids (e.g. Lindner \& Anderson 1956, Farmer \& Al-Attar 1981, Hill \& Wassenberg 1985, Wassenberg \& Kerr 1990).

Estimates of tag-induced mortality of eastern king prawns tagged with Petersen discs or anchor tags (Lucas et al. 1972) were greater and less, respectively, than in the present study. Results of Lucas et al. (1972) were, however, confounded by great mortality amongst control prawns. Generally, mortality of prawns tagged with streamer tags is less than in those tagged with Petersen discs (e.g. Marullo et al. 1976, Farmer \& Al-Attar 1981)

Incidences of tags found dislodged from tagged prawns coincided to some extent with moulting. This was especially so during Days 33 to 37 (Fig. 3). Tag shedding at the time of moulting has long been a problem in tagging experiments on crustaceans (e.g. Scarratt 1970, Prentice \& Rensel 1977). Howe \& Hoyt (1982), in laboratory experiments on Penaeus aztecus, attributed shedding of tags to cannibalism. Tags recovered during the present study had cuts and indentations similar to those described by Howe \& Hoyt (1982). In the present study, however, most prawns that shed their tag (identified by the wound made where the tag was inserted) were recovered. This suggested that such prawns were able to avoid attack. Tag shedding in the present study was therefore most likely associated with ecdysis.

The high proportion of tag shedding in the present study caused estimates of apparent mortality to be high. Results suggested that using the small streamer tag caused less apparent mortality in tagged eastern king prawns in this study than did large tags. Apparent mortality among tagged prawns released in the field may also be reduced by delaying the release of tagged prawns until $6 \mathrm{~d}$ after tagging. This was the period when most apparent mortality occurred in the present study. Delaying the release of tagged prawns into the field would reduce the effect of this early apparent mortality and therefore provide a more accurate estimate of the number of tagged prawns surviving in the population in the field, and hence more accurate estimates of mortality and recruitment processes.

In many studies, regression analysis has been used to determine a functional relationship between either mor- 
tality or survival and time (e.g. Hill \& Wassenberg 1985 , Jewett 1986). Often, data are the sequential numbers or proportions surviving or dying (or being recaptured) from a single starting population, and as such, these are not independent. One of the important assumptions of regression analysis is that data are independently sampled (Snedecor \& Cochran 1978, p. 141). There is no simple method for determining the effects of non-independence of data in calculations of regression coefficients. If data are not independent, the effects observed in experimental animals cannot be assumed to be representative of what would normally occur. Because data in the present study were not independent in the sense above, a functional relationship between apparent mortality and time was not determined. Rarely are independently sampled data examined for analyses of mortality. This should be considered when designing studies to estimate survival or mortality.

The sizes of streamer tags compared in the present study cannot be recommended for tagging eastern king prawns within the length range used here. Although using the small tag reduced tag-induced mortality and apparent mortality, the latter was great nonetheless. The work of Glaister (1983) showed that streamer tags were suitable for tagging larger eastern king prawns, though he did not consider the size-dependence of taginduced mortality in his study. Farmer \& Al-Attar (1981) concluded that streamer tags $(95 \mathrm{~mm}$ long and $3 \mathrm{~mm}$ wide) should only be used to tag Penaeus semisulcatus larger than $80 \mathrm{~mm}$ total length. On the other hand, Wassenberg \& Kerr (1990) concluded from laboratory experiments that $P$, esculentus and $P$. merguiensis as short as $18 \mathrm{~mm} \mathrm{CL}$ could be tagged with streamer tags $(42 \mathrm{~mm}$ long and $2 \mathrm{~mm}$ wide) before there was any significant tag-induced mortality. Further work is required to determine the smallest practical size of streamer tag and length of prawn that can be used when doing tagging experiments in the field on $P$. plebejus.

Acknowledgements. We are grateful to various staff of the NSW Agriculture \& Fisheries who assisted in establishing and monitoring the experiment. Ms M. Leedow helped with the experimental design whilst Messrs D. Reid and G. Gordon and Ms M. King assisted with data analysis. Drs R. Kearney, S. Kennelly and A. Underwood made helpful comments on drafts of this manuscript.

\section{LITERATURE CITED}

Beverton, R. J. H., Holt, S. J. (1957). On the dynamics of exploited fish populations. U. K. Min. Agric. Fish., Fish. Invest. (Ser. II) 19: 1-533

Cormack, R. M. (1968). The statistics of capture-recapture experiments. Oceanogr. mar. Biol. A. Rev. 6: 455-506

Farmer, A. S. D. (1981). A bibliography on the releasing, recruitment, mortality and marking of penaeid shrimps. Kuwait Bull. mar. Sci. 2: 83-108

Farmer, A. S. D., Al-Attar, M. H. (1981). Results of shrimp marking programmes in Kuwait. Kuwait Bull. mar. Sci. 2: $53-82$

Garcia, S. Le Reste, L. (1981). Life cycles, dynamics, exploitation and management of coastal penaeid shrimp stocks. FAO Fish. tech. Pap. 203: 1-215

Glaister, J. P. (1983). Dynamics of the eastern Australian king prawn population. Ph. D thesis, University of New South Wales

Glaister, J. P., Lau, T., McDonall, V C. (1987). Growth and migration of tagged eastern Australian king prawns Penaeus plebejus Hess. Aust. J. mar Freshwat. Res. 38: 225-241

Glaister, J. P., Montgomery, S. S., McDonall, V C. (1990). Yield per recruit analysis of eastern king prawns Penaeus plebejus Hess, in eastern Australia. Aust. J. mar. Freshwat. Res. 41: 175-197

Greenland, D. C., Bryan, J. D. (1974). Anchor tag loss in channel catfish. Prog. Fish Cult. 36 (3): 181-182

Hampton, J., Kirkwood, G. P. (1989). Tag shedding by southern bluefin tuna Thunnus maccoyii. Fish. Bull. U.S. 88 (2): 313-321

Hill, B. J., Wassenberg, T J. (1985). A laboratory study of the effect of streamer tags on mortality, growth, moulting and duration of nocturnal emergence of the tiger prawn Penaeus esculentus (Haswell). Fish. Res. 3: 223-235

Holt, B. (1982). Short-term mortality of tagged shrimp during field tagging experiments. NOAA Tech. Mem. NMFFSEFC 97, p. 1-10

Howe, N. R., Hoyt. P. R. (1982). Mortality of juvenile brown shrimp Penaeus aztecus associated with streamer tags Trans. Am. Fish. Soc. 111: 317-325

Jakobsson, J. (1970). On fish tags and tagging. Oceanogr. mar. Biol. A. Rev. 8: 457-499

Jewett, S. C. (1986). Mortality of spot shrimp associated with streamer tags. N. Am. J. Fish. Mgmt 6: 260-263

Kirkwood, G. P., Walker, M. H. (1984). A new method for estimating tag shedding rates, with application to data for Australian salmon, Arripis trutta esper Whitley. Aust. J. mar. Freshwat. Res. 35: 601-606

Klima, E. F. (1981). The National Marine Fisheries Service shrimp research program in the Gulf of Mexico. Kuwait Bull. mar. Sci. 2: 185-207

Lindner, M., Anderson, W S. (1956). Growth, migrations, spawning and size distribution of shrimp, Penaeus setiferus. Fishery Bull. Fish Wildl. Serv. U.S. 56: 555-645

Lucas, C. (1974). Preliminary estimates of stocks of the king prawn, Penaeus plebejus, in south-east Queensland. Aust. J. mar Freshwat. Res. 25: 35-47

Lucas, C., Young, P. C., Brundritt, J. K. (1972). Preliminary mortality rates of marked king prawns Penaeus plebejus, in laboratory tanks. Aust. J. mar. Freshwat. Res. 23: 143-149

Maguire, G. B., Bell, J. D. (1981). The effects of fish on growth and survival of school prawns Metapenaeus macleayi (Haswell) in some Australian brackish water farm ponds. Aquaculture 24: 267-283

Maguire, G. B., Leedow, M. I. (1983). A study of the optimum stocking density and feed rate for school prawns Metapenaeus macleayi (Haswell) in some Australian brackish water farming ponds. Aquaculture 30: 285-297

Marullo, F., Emiliani, D. A., Caillouet, C. W., Clark, S. H. (1976). A vinyl streamer tag for shrimp (Penaeus spp.). Trans. Am. Fish. Soc. 105: 658-663

Menz, A., Blake, B. F. (1980). Experiments on the growth of Penaeus vannamei. J. exp. mar. Biol. Ecol. 48: 99-111 
Montgomery, S. S. (1990). Movements of juvenile eastern king prawns Penaeus plebejus, and identification of stock along the east coast of Australia. Fish. Res. 9: 189-208

Neal, R. A. (1969). Methods of marking shrimp. F.A.O. Fish Rep. 57: 1149-1165

Penn, J. W. (1975). Tagging experiments with western king prawn Penaeus latisulcatus Kishinouye. I. Survival, growth and reproduction of tagged prawns. Aust. J. mar Freshwat. Res. 26: 197-211

Penn, J. W. (1981). A review of mark-recapture and recruitment studies on Australian penaeid shrimp. Kuwait Bull. mar. Sci. 2: 227-247

Potter, M. A. (1975). Movements of the eastern king prawn Penaeus plebejus in southern Queensland waters. In: Young, P. C. (ed.) First National Prawn Seminar. Proceedings of Seminar, 22-27 November 1973. Maroochydore, Australia. Australian Gov. Pub. Serv., Canberra, p. 10-17

Prentice, E. F., Rensel, J. E. (1977). Tag retention of the spot prawn Pandalus platyceros, injected with coded wire tags J. Fish. Res. Bd Can. 34: 2199-2203

This article was presented by A. J. Underwood, Sydney, Australia
Rounsfell, G. A. (1963). Marking fish and invertebrates. Fishery Leafl. Fish Wildl. Serv. U.S. 549: 1-12

Ruello, N. V (1975). Geographic distribution, growth and breeding migration of the eastern king prawn Penaeus plebejus (Hess). Aust. J. mar. Freshwat. Res. 36: 343-354

Scarratt, D. J. (1970). Laboratory and field tests of modified sphyrion tags on lobsters (Homarus americanus). J. Fish. Res. Bd Can. 27: 257-264

Sheridan, P. F., Patella, F. J., Baxter, N., Emilian, D. A. (1987) Movements of brown shrimp, Penaeus aztecus, and pink shrimp, $P$. duorarum relative to the U.S.-Mexico border in the western Gulf of Mexico. Mar. Fish. Rev. 49: 14-19

Snedecor, G. W., Cochran, W. G. (1978). Statistical methods. lowa State University Press, Ames, lowa

Somers, I. F., Kirkwood, G. P. (1984). Movements of tagged tiger prawns, Penaeus spp, in the Western Gulf of Carpentaria. Aust. J. mar. Freshwat. Res. 35: 713--723

Wassenberg, T J., Kerr, J. (1990). Wound healing in prawns tagged with streamer tags, and the effect of tag placement and prawn size on survival rate. Fish. Res. 9: 209-218

Manuscript first received: September 17, 1990

Revised version accepted: June 28, 1991 